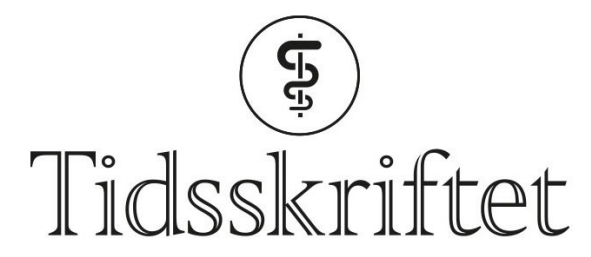

DEN NORSKE LEGEFORENING

\title{
Ulik dødelighet ved ulike antidiabetika
}

FRA ANDRE TIDSSKRIFTER

PETTER MORTEN PETTERSEN

Tidsskriftet

SGLT2-hemmere og GLP1-agonister gir lavere dødelighet enn DPP4-hemmere ved type 2diabetes, viser ny metaanalyse.

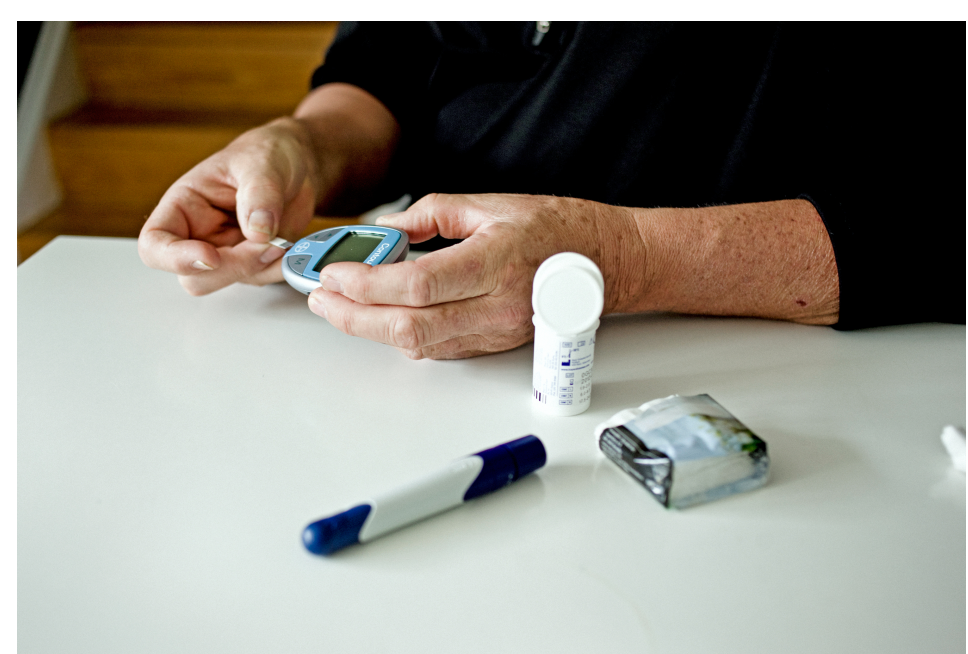

Illustrasjonsfoto: Morten Germund/Ritzau Scanpix

De siste årene har det kommet en lang rekke nye legemidler mot type 2-diabetes, og det foreligger mange studier om dødelighet ved bruk av slike midler. I en nettverksmetaanalyse, basert på 236 studier med til sammen flere enn 175 ooo pasienter, ble dødeligheten ved bruk av tre klasser antidiabetika sammenlignet, dvs. natriumglukosekotransportørhemmere (sodium-glucose cotransporter 2 inhibitors, SGLT2-hemmere), glukagonlignende peptid 1-agonister (glucagon-like peptide 1 agonists, GLP1-agonister) og dipeptylpeptidase-4-hemmere (dipeptidyl peptidase 4 inhibitors, DPP4-hemmere) (1).

Behandling med SGLT2-hemmere og GLP1-agonister ga signifikant reduksjon i dødelighet, uavhengig av dødsårsak, sammenlignet med placebo eller ingen behandling (hasardratio henholdsvis o,8o og o,88). Det samme gjaldt ved sammenligning med DPP4-hemmere (hasardratio henholdsvis 0,78 og o,86). DPP4-hemmere ga ingen signifikant reduksjon i dødelighet sammenlignet med placebo eller ingen behandling.

- Denne metaanalysen bekrefter funn fra ni store randomiserte, kontrollerte studier samt observasjonsstudier om effektene av nyere antidiabetika, sier Kåre I. Birkeland, som er professor ved Avdeling for transplantasjonsmedisin ved Oslo universitetssykehus. - 
Nettverksanalyser som denne gir indirekte informasjon, og vi savner fortsatt prospektive studier som direkte sammenligner de ulike medikamentene.

Internasjonale og norske behandlingsretningslinjer stiller i stor grad legene fritt til å velge mellom 5-6 ulike klasser blodsukkersenkende legemidler når metformin ikke er tilstrekkelig, sier Birkeland. I Norge brukes nå DPP4-hemmere mye som andrevalg etter metformin, sier Birkeland.

\section{LITTERATUR:}

1. Zheng SL, Roddick AJ, Aghar-Jaffar R et al. Association between use of sodium-glucose cotransporter 2 inhibitors, glucagon-like peptide 1 agonists, and dipeptidyl peptidase 4 inhibitors with all-cause mortality in patients with type 2 diabetes: a systematic review and meta-analysis. JAMA 2018; 319: 1580 91. [PubMed][CrossRef]

Publisert: 21. august 2018. Tidsskr Nor Legeforen. DOI: 10.4045/tidsskr.18.039o

(C) Tidsskrift for Den norske legeforening 2020. Lastet ned fra tidsskriftet.no 